\title{
EFFECT OF TWO STORAGE METHODS ON THE KEEPING AND SENSORY QUALITIES OF FOUR PLANTAIN VARIETIES
}

\author{
Sugri $\mathrm{I}^{1}$ and PNT Johnson ${ }^{2 *}$
}

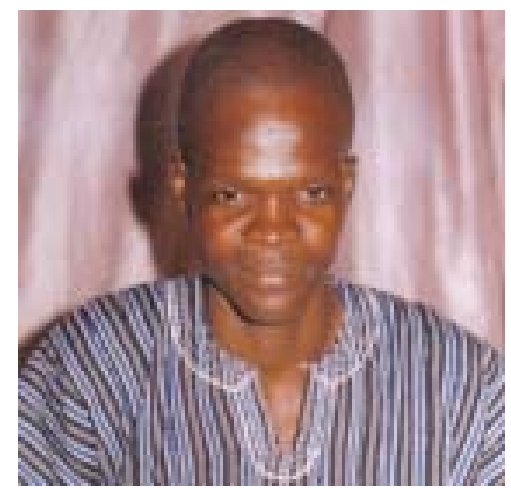

\section{Sugri}

*Corresponding author email: pntjohnson@ fri.csir.org.gh or paanii.johnson@gmail.com

${ }^{1}$ Dept. of Crop Science, College of Agric. \& Consumer Sciences, University of Ghana, Legon, Accra, Ghana

${ }^{2}$ Food Research Institute, (CSIR), Box M.20, Accra, Ghana 


\section{ABSTRACT}

Plantains are an important cash and subsistence crop for the small-scale producers all year round in most parts of the tropical world including Ghana. Unfortunately, the plantain industry is still characterised by high post-harvest losses. Given that plantains are still used in the fresh state, any intervention aimed at reducing the losses must have this in mind. This paper is on a study of the influence of passive evaporative cooling (PEC) and modified atmosphere (MA) on the keeping and sensory qualities of four plantain varieties, Apem, Apentu, Oniaba and Asamienu, during the preclimacteric and post-climacteric storage stages. The PEC was achieved by using sawdust held in jute sacs moistened to varying moisture holding capacities (mhc) of $25 \%, 50 \%$ and $75 \%$. The MA storage was achieved using a number of storage treatment combinations involving two types of low density polyethylene pouches, sawdust and potassium permanganate, as an ethylene scrubber. The PEC at 50\% mhc produced the longest green life of 28, 26, 16, and 15 days and post-climacteric storage life of 34, 32, 22 and 21days for Apem, Apentu, Oniaba and Asamienu, respectively. Peel splitting disorder did not occur at any of the mhc levels used for the study. However, all varieties were susceptible to finger drop after three weeks. The MA exhibited varying effect $(P<0.001)$ on post-climacteric storage life. The use of $\mathrm{KMnO}_{4}$ increased green life by 3 to 6 days across treatments. Inclusion of moist sawdust in MA increased green life of Apem from 11 to 16 and further to 18 days when $\mathrm{KMnO}_{4}$ was added. Principal component analysis established that for any one variety of plantain, all treatments received statistically comparable scores for colour, flavour, mouth feel, taste and overall acceptability by the trained sensory panel of ten, except for texture. There were significant differences among varieties for all sensory attributes. Thus, PEC and MA can be promoted as low-cost systems for the handling and storage of plantain during its marketing.

Key words: Plantains, storage, keeping, sensory qualities 


\section{INTRODUCTION}

Plantains (Musa spp. AAB and ABB) are an important cash and subsistence crop for the small-scale producers all year round. The crop is attractive to farmers due to the low labour requirement of about 80 man-days per hectare for production compared to 122, 162 and 310 days for corn, rice and cassava, respectively [1]. Plantain is thus believed to be the cheapest starchy staple that can be produced the world over. In Ghana, plantains are consumed as main meal and snack at all stages of ripening: green (unripe), yellow-green, ripe or over-ripe. The fruits provide available food energy (AFE) of $172 \mathrm{Kcal} /$ inhabitant/day [2], contribute up to $9.5 \%$ of total national calorie intake, a per capita annual consumption of $101.8 \mathrm{~kg}$ per head [3], and constitute about $13.1 \%$ of the Agricultural Gross Domestic Products (AGDP) [4]. Over the last few years, the production of plantain has been increasing tremendously due to the introduction of some new varieties resistant to black sigatoka virus disease. Unfortunately, very high post-harvest losses, as high as 10 to 30 percent, are associated with the crop. Many reasons account for this, the main being that they are highly perishable. Losses are severe among resource-poor farmers who lack sophisticated storage facilities to reduce post-harvest losses. Processing the fruits into commercial preservable products will naturally have been the main intervention to reduce these losses. Unfortunately, most families prefer to use plantains in the fresh and unprocessed form in cooking. Thus, an appropriate intervention would be the use of cost-effective methods to extend the shelf-life of the plantains, especially during the matured green stage. This paper concerns a study to evaluate the effect of using passive evaporative cooling and modified atmosphere storage on the keeping and sensory qualities of four plantain varieties, Apentu, Apem, Asameinu and Oniaba during the pre- and post-climacteric periods.

\section{MATERIALS AND METHODS}

\section{Plantain Samples}

Uniformly matured green fruits of four varieties were obtained from an arranged supplier in a local market in Accra. The varieties were: two French plantains (Apem and Oniaba), a False Horn plantain (Apentu) and True Horn (Asamienu).The plantain bunches were de-handed at the market to facilitate handling. The fruits were precooled with a mist of water upon arrival at the storage room.

\section{Passive Evaporative Cooling (PEC)}

Sawdust in jute sacs moistened to varying moisture holding capacity (mhc) of $25 \%$, $50 \%$ and $75 \%$ was used to incubate the plantains. The treatment combinations used for the experiment is as shown in Table 1. Daily watering was done during mornings. Further cooling was done by holding fruits in well-shaded and ventilated area. Postharvest disorder indices monitored were peel splitting and finger drop. 


\section{Modified Atmosphere Storage}

Two low-density polyethylene (LDPE) pouches of thicknesses 0.02 and $0.03 \mathrm{~mm}$, each with dimension $70 \times 125 \mathrm{~cm}$ were used. Sackets of $\mathrm{KMnO}_{4}$ were impregnated into the pouches as ethylene absorbent at a ratio of $1 \mathrm{~g} / \mathrm{kg}$ of fruit [5] and [6]. Dry and moist sawdust were also added. The control treatments were fruit sealed in PE only and fruits stored at room temperature. Each variety was subjected to all treatment combinations described in Table 2.

\section{Analysis of Keeping Quality Indices}

\section{Pulp to peel ratio}

Fingers were hand-peeled and the weights of the peel and pulp were determined separately on a digital balance (Metler, PM- 4800). These were done at ripening stages 1,4 , and 6 . The pulp to peel ratio was obtained by dividing the pulp weight by peel weight [7].

\section{Physiological weight loss}

This was determined from the total weight loss (TWL) expressed as percentage of the original weight lost during the storage period. Weight loss percentage per day (WL/D) was calculated by dividing total weight loss by the number days to reach stage 6 [7].

\section{Sensory Evaluation}

A five-point Hedonic scale was used to score samples for taste, colour, flavour, texture, mouth feel and overall acceptability (Table 3). Plantain samples were roasted in an oven with the temperature set at medium to high. Coded samples per each treatment were served to each member of 13 trained panellists.

\section{Statistical Analysis}

Data were analyzed using Genstat statistical package. The data were subjected to ANOVA and test of significance at 1 and 5\% probability levels. A data reduction procedure using the principal component analysis (PCA) was done for the sensory attributes. A further data reduction technique using principal component analysis (PCA) was done to establish variations, patterns and relations in the data [8].

\section{RESULTS}

\section{Effect on the pre-climacteric period}

Figure 1 shows an overall increase in pre-climacteric period as the $m h c$ increased from 25 to $75 \%$. However, no significant differences (P>0.05) were noted between 50 and $75 \% \mathrm{mhc}$. Storage in wet jute sacs did not cause peel splitting disorder. All varieties were susceptible to finger drop when stored at all $m h c$ after three weeks. Table 4 indicates that inclusion of dry or moist sawdust extended green life by 4 days. This was extended to 6 days when $\mathrm{KMnO}_{4}$ was added. The thickness of the polyethylene did not affect these results. The effect of sawdust moisture level on preclimacteric life was not consistent. Table 4 also shows that Apem recorded

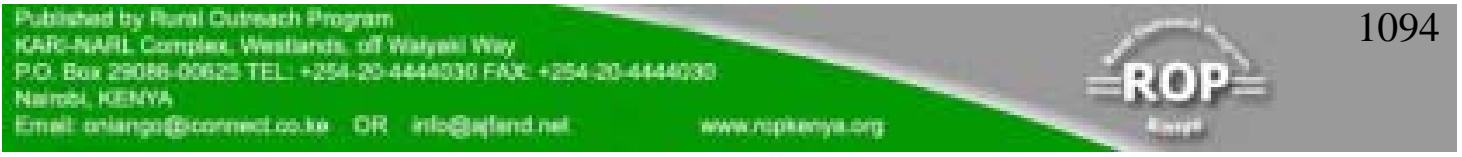


consistently longer $(\mathrm{P}<0.001)$ green life (16 days) than Apentu, Asamienu and Oniaba (12, 14,15 days), respectively.

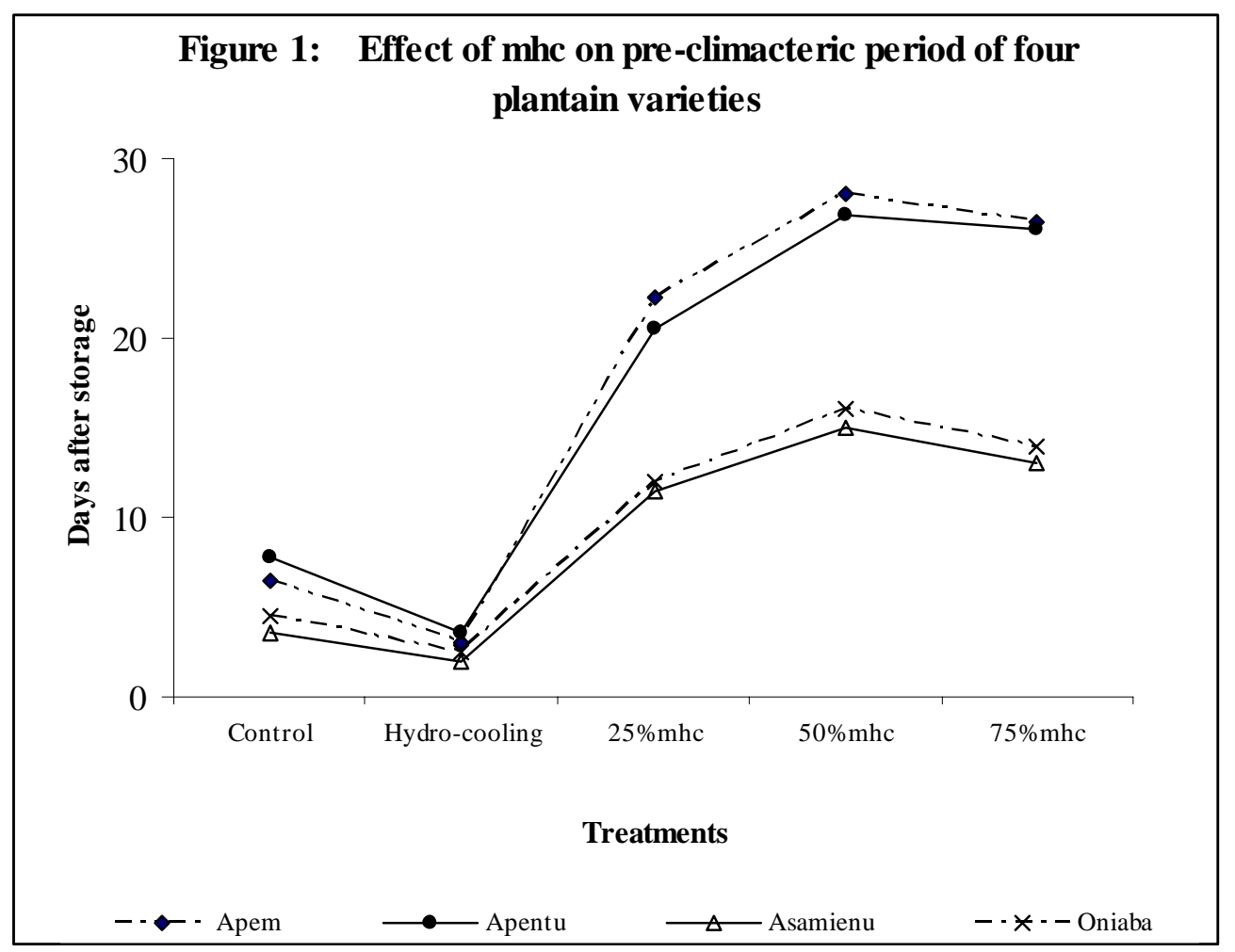

\section{Effect on the post-climacteric period}

Table 5 shows the effect of mhc on average number of days at senescence. The implication is that all the varieties will maintain good eating qualities for 3 to 5 days after full ripening. The effect of mhc on storage life is shown in Figure 2. The mhc at $50 \%$ and $75 \%$ recorded the longest storage life across varieties due the longer preclimacteric life. Treatment interactions $(\mathrm{P}<0.001)$ show Apem and Apentu recording longest shelf life $(34 ; 32$ days) when stored at $50 \%$ and $75 \%$ mhc, respectively. The storage lives of Apem and Apentu (23, 24 days) when compared to Asamienu and Oniaba (16 days) did not statistically vary ( $\mathrm{P}>0.001)$ when assessed on the basis of the treatment combinations. However, there were significant differences in the two sets of plantains. The use of the MA recorded an average storage life period of 15 to 28 days across treatments (Table 6). The storage life demonstrates the length of time fruits stored in the various MA treatments would be available for human consumption. 


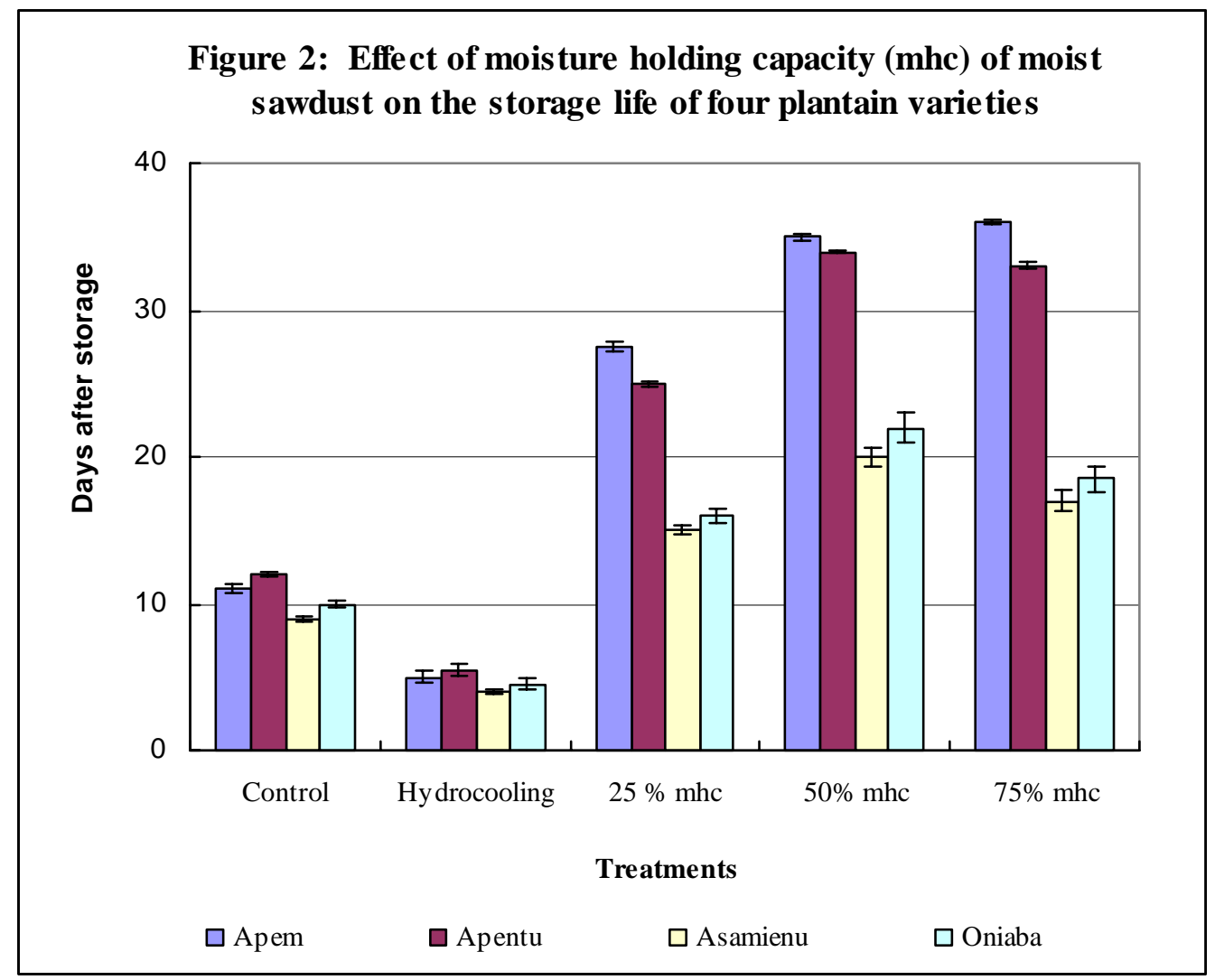

\section{Effect on physiological weight loss}

All varieties showed decreasing physiological weight loss (PWL) with increasing mhc. Fruits held at 50\% and $75 \%$ mhc showed low weight loss per day, whilst fruits stored at room temperature showed the greater weight loss. The total weight losses due to the use of $50 \%$ and $75 \%$ mhc were, however, comparable (Figure 3). Apem and Apentu suffered higher total weight losses $(9.63 \% \& 9.28 \%)$ and daily weight loss ( $0.83 \%$ and $0.84 \%)$, compared Oniaba and Asamienu with total weight loss of $7.78 \%$ $\& 7.34 \%$ and daily weight loss of $0.58 \& 0.52 \%$, respectively.

The effect of MA on total weight loss is shown in Table 7. The treatment interactions showed that the incorporation of moist sawdust significantly $(\mathrm{P}<0.001)$ reduced total weight loss. Treatments with prolonged green life showed higher weight loss. 


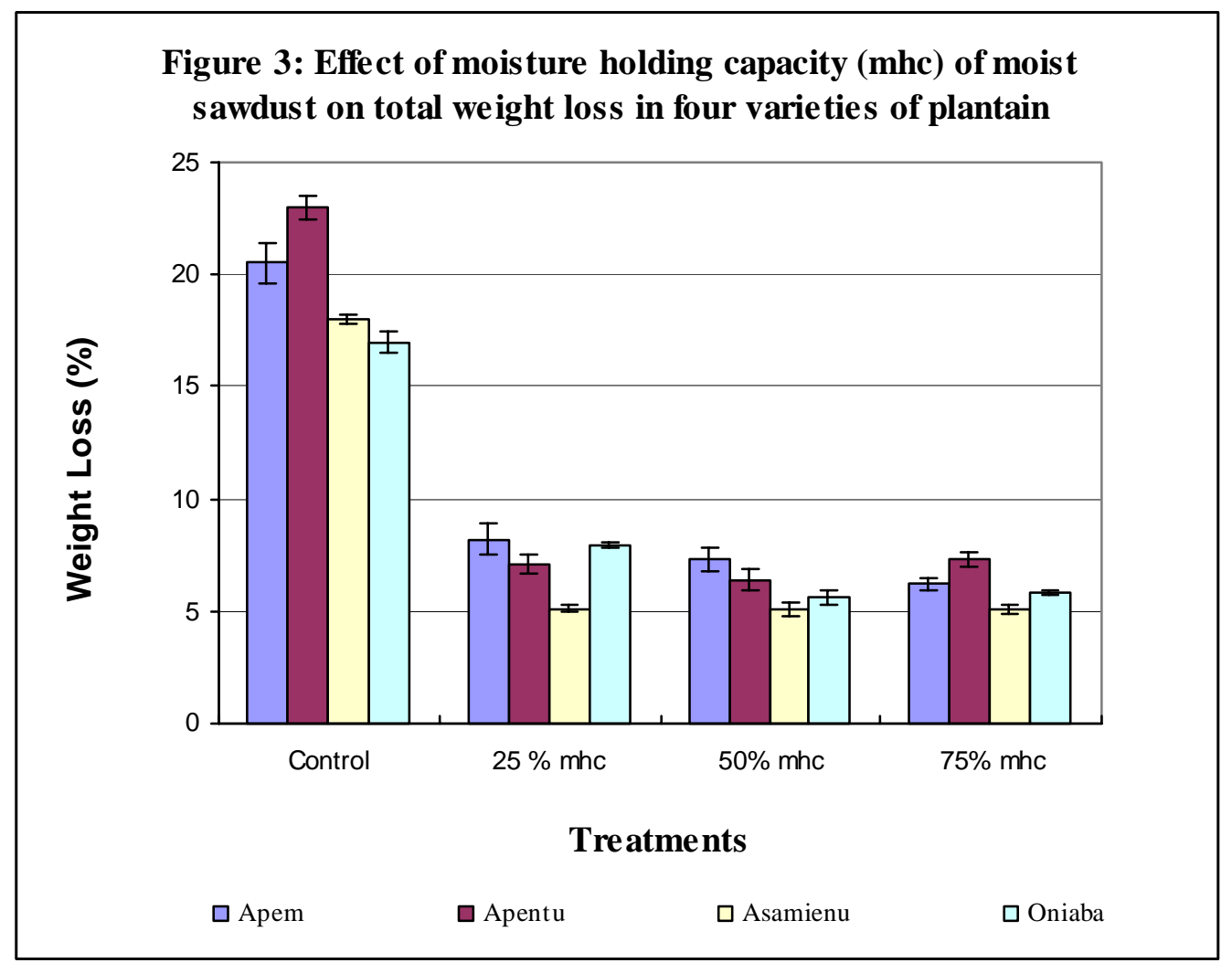

\section{Effect on physiological disorders}

Fruits immersed in water (hydro-cooling) were susceptible to peel splitting and showed overt symptoms within 3 days of storage. Irrespective of the mhc, fruits stored in the PEC did not suffer from peel splitting. However, all the varieties were susceptible to finger drop disorder, particularly after three weeks of storage.

\section{Effect on pH, Total Titratable Acidity (TTA) and Total Soluble Solids (TSS)}

The different methods of storage had no influence on the pulp pH, TTA and TSS. Whilst there was a gradual decrease in $\mathrm{pH}$ and TTA, there were, however, dramatic increases in the TSS values as the fruits ripen. The pulp pH of green Apentu, Apem, Asamienu and Oniaba were 6.12, 6.01, 5.98 and 5.90 but when fully ripe had reduced to $4.52,4.41,4.42$ and 4.48 , respectively.

\section{Effect on sensory qualities}

For any one variety of plantain, all treatments received statistically comparable (P > 0.05) scores for colour, flavour, mouth feel, taste and overall acceptability, except for texture. Fruit flavour, taste, mouth feel and colour were positively correlated. Higher mhc (75\%) influences fruit firmness. Fruit stored at room temperature, 25\%, and 50\% mhc received higher scores for firm texture $(3.63 \& 3.25 \& 3.27)$ than at $75 \%$ mhc (2.88).. Loss of firmness was severe in Apem and Oniaba (2.25 \& 2.75) compared to Apentu and Asamienu of (3.33 \& 3.18). Difference in colour was conspicuous among varieties, with average scores for Asamienu, Oniaba and Apentu of 3.77, 3.67 and 3.67, respectively, indicating yellowish pulp colour. Panel scores show Apentu,

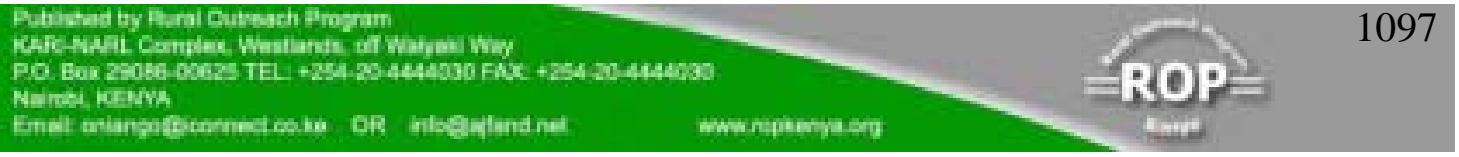


Oniaba and Apem were sweeter (3.65, 3.63 \& 3.58) than Asamienu (3.25). Principal component analyses on the effect of mhc on sensory attributes could be explained using two indices: principal component one (PC1) consisting of mouth feel, flavour and tastes accounted for $36.67 \%$ of data variation, and PC2 made of texture and colour accounted for $21.1 \%$ of variability of the data (Figure 4).

The MA treatments did not adversely affect the sensory qualities. A range of scores for flavour (2.17 to 3.67), taste (2.50 to 5.50) and mouth feel (2.33 to 3.50) across treatments suggest that no off-flavours or astringent tastes were noticeable. The use of dry or wet sawdust and $\mathrm{KMnO}_{4}$ did not improve flavour, taste and mouth feel. Fruits stored in PE pouches incorporated with dry sawdust were judged to have firmer texture by sensory panellists. Principal component analyses of sensory attributes (Figure 5) show PC1 consisting of taste, flavour, mouth feel and colour formed a cluster and together accounted for $38.3 \%$ of data variation, whilst PC2 made of texture accounted for $21.8 \%$ of data variability. It thus appeared that texture characteristic of samples was the critical attribute to consider for sensory quality evaluation.

\section{Figure 4: Loading plot from principal component analyses (PCA)of sensory attributes of plantains stored by PEC}

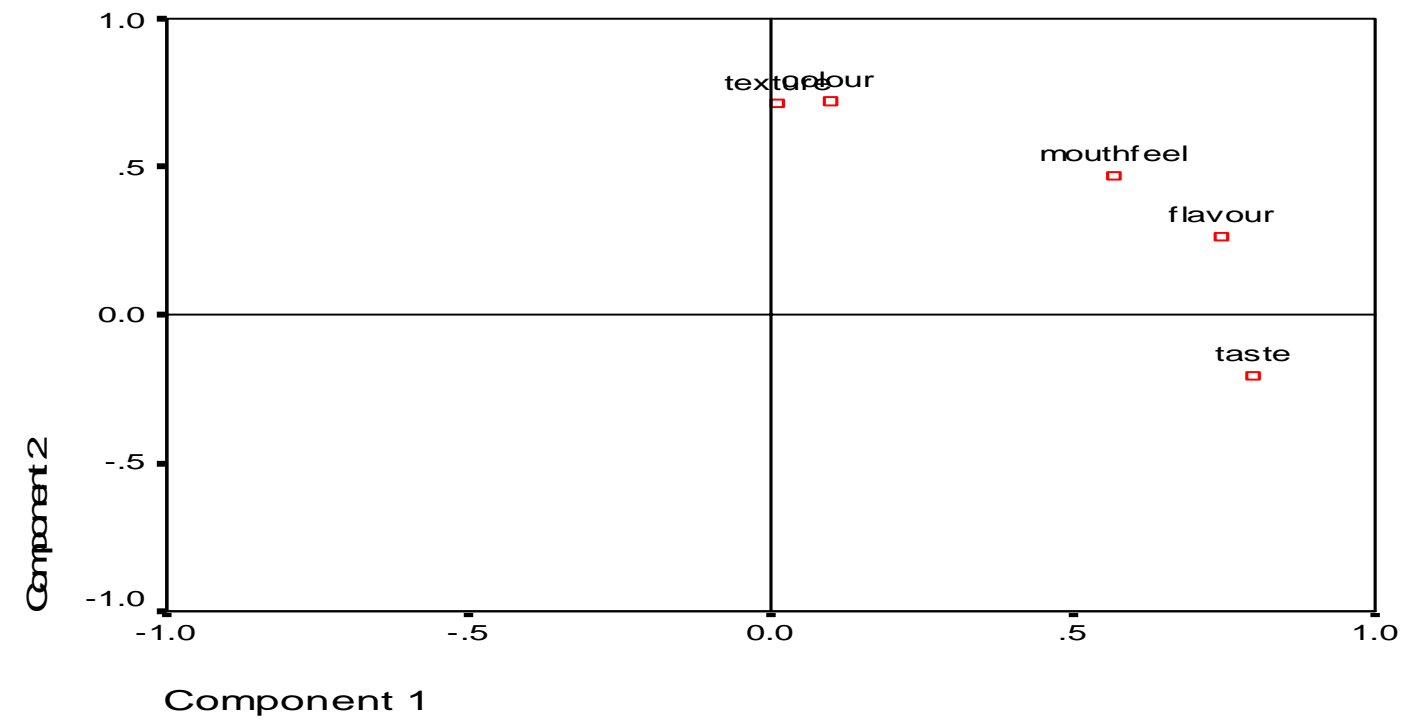




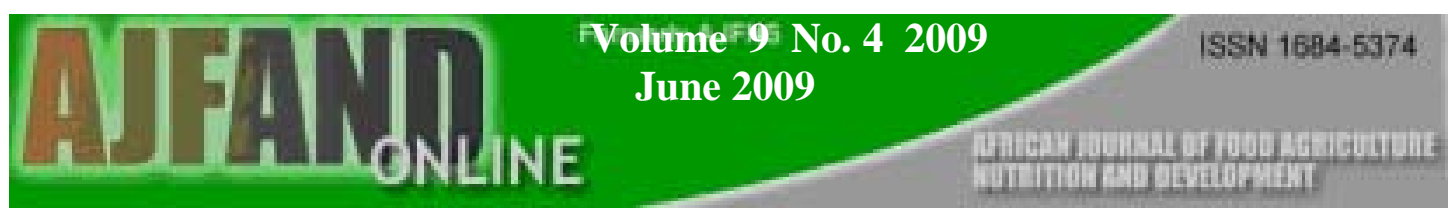

Figure 5: Loading plot from principal component analyses (PCA) of sensory attributes of plantains stored by MA

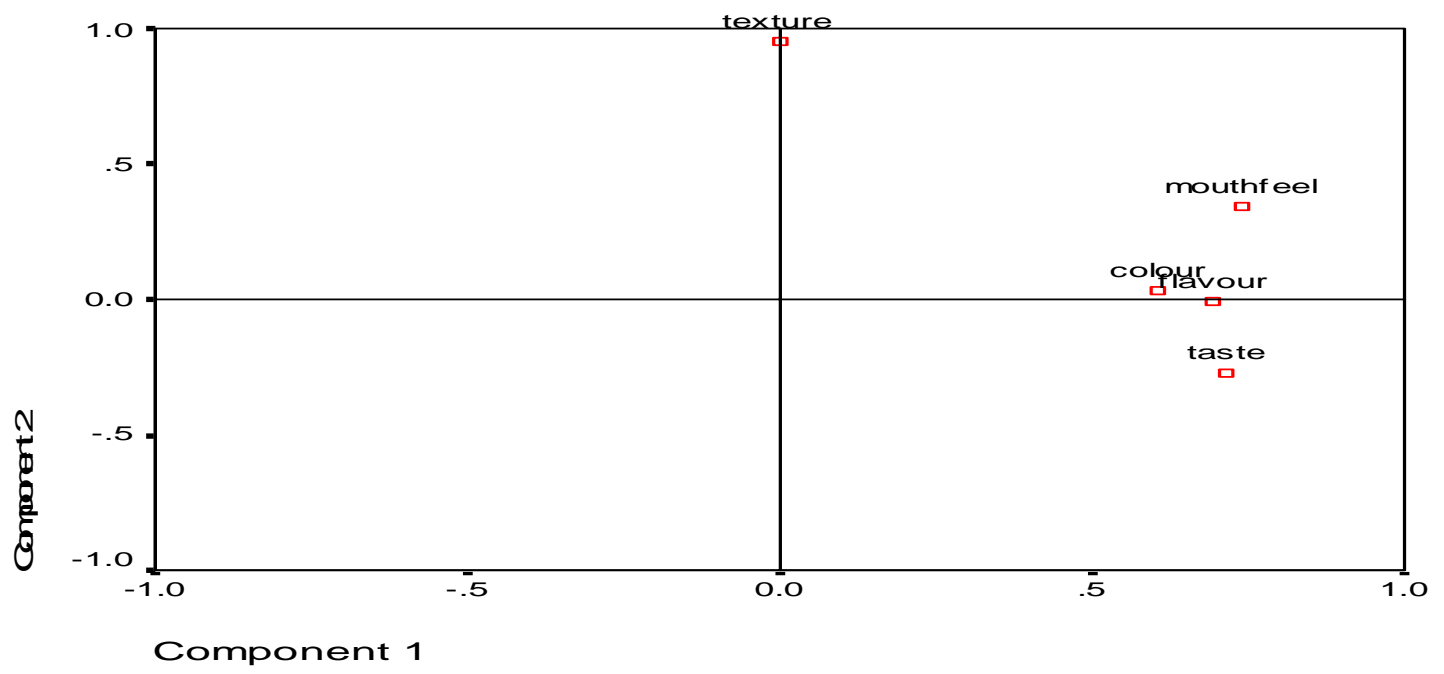

\section{DISCUSSION}

The post-harvest life of plantain consists of three physiological phases: the preclimacteric, climacteric and senescence [9, 10]. The pre-climacteric period corresponds to the period after harvest in which the fruits remain green and firm. The fruits at this stage have low respiration rate and produce low levels of ethylene. Using an appropriate storage method to delay the commencement of climacteric period which results in increased respiration and ethylene emission seems to be the key to prolonging the storage life of plantain. This is because ripe fruits respire at approximately four times the rate of green fruits and consequently use up sugar resources at higher rate mainly as respiratory substrates [11]. This explains why ripe fruits deteriorate faster than green fruits.

The three mhc exhibited varying effects on the pre-climacteric life and post-ripening qualities of varieties. Storing plantains at/near the optimum temperatures of 13.5 to $14.5{ }^{\circ} \mathrm{C}$ and 90 to $95 \% \mathrm{RH}$ decreases the rate of respiration, transpiration and ethylene sensitivity [12]. The rate of respiration and transpiration increases exponentially as external temperature increases over a range from 15 to $35^{\circ} \mathrm{C}$, according to van Hoff temperature relationship. Increase in physiological processes relates inversely to storage life. It has been reported that any $1{ }^{\circ} \mathrm{C}$ reduction in temperature extends shelf life by 1 to 2 days [11]. The observed extended pre-climacteric period can, therefore, be attributed to the passive evaporative cooling (PEC) used. This is because during the study, the PEC consistently maintained an average of $3{ }^{\circ} \mathrm{C}$ lowering of the temperature and $4 \%$ increased of $\mathrm{RH}$ over the ambient conditions. These conditions decreased the vapour pressure deficit between the fruit and its environment and thus further reduced the respiration and ethylene sensitivity of fruits [13] and [14]. The efficiency of this method, however, relies on ambient temperature, humidity and wind velocity to generate the necessary cooling to temperatures below ambient air. The degree of cooling with natural ventilation is limited to 1 to $2{ }^{\circ} \mathrm{C}$ above the wet bulb of

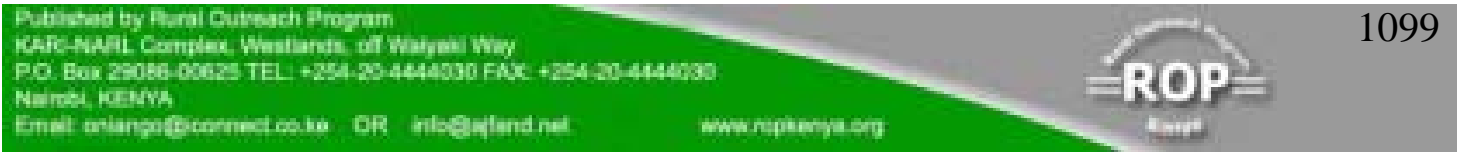




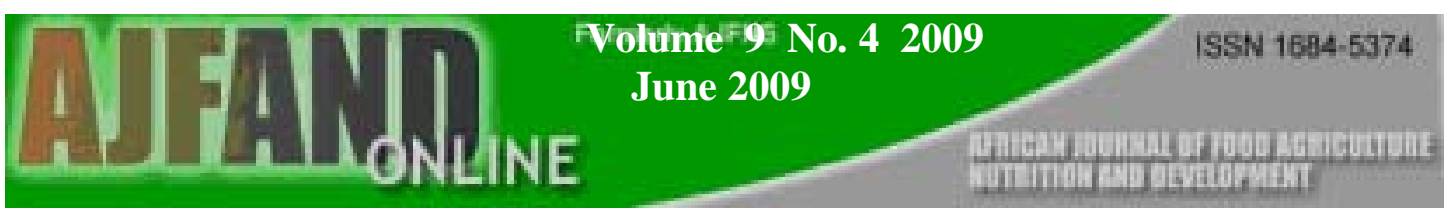

ambient temperatures. Nonetheless, the prolonged pre-climacteric period shows the potential of PEC under tropical conditions.

Peel splitting occurrence is attributed to water imbalance in fruits [15]. The plantain peel is susceptible to wetting, when the fruits are immersed in water. The peel absorbs free water and swells up to exceed the stretching limit of the space provide by the peel, giving an extra external force and rendering the peel to split and even more extensively to the pulp [15]. Hydro-cooling may be more appropriate for commodities tolerant of wetting, chlorine and water beating, but can be used as a pre-cooling method for plantains. This can be explained that, the process of evaporative cooling does not create free water that is readily absorbed by peel. This physiological disorder results in softening and weakening of the pedicel which cause the individual fruits to dislodge from the crown.

Several workers have established that the amount of $\mathrm{CO}_{2}, \mathrm{CO}, \mathrm{O}_{2}$, nitrogen and ethylene gases in storage atmospheres have effect on respiration and subsequent ripening qualities of fruits [16], [6] and [17]. In addition, studies on modified atmosphere (MA) storage show that a passive equilibrium atmosphere of 2 to $5 \% \mathrm{O}_{2}$ and 2 to $5 \% \mathrm{CO}_{2}$ is attainable when plantains are stored in semi permeable polymeric [18], [6] and [7]. These changes in atmospheric conditions delay ripening by reducing the rate of respiration and ethylene production [19]. The prolonged pre-climacteric period of fruits held in the two polyethylene pouches indicates that MA was attained. The polyethylene (PE) pouches used are semi-permeable to gases and water vapour. This property should support modification of the composition of gases and water vapour in the storage atmosphere, given that $\mathrm{CO}_{2}$ produced by the respiring fruits increases whiles $\mathrm{O}_{2}$ levels deplete [6].

The effect of potassium permanganate $\left(\mathrm{KMnO}_{4}\right)$ on the pre-climacteric period of plantain fruits is indicated by the difference in length of green life of fruits held in the two experimental conditions: holding fruits with sawdust only, and varying the atmosphere by the presence of $\mathrm{KMnO}_{4}$. This extended green life period can be attributed to decrease in ethylene production following exposure to $\mathrm{KMnO}_{4}$, which is consistent in many climacteric fruits [20]. The $\mathrm{KMnO}_{4}$ inhibited the onset of ethylene system II, which initiates, coordinates and accelerates the process of ripening of climacteric fruits [21]. The varieties were not sensitive to the variation in PE thickness $(0.02$ and $0.03 \mathrm{~mm})$. Probably, this was not wide enough to show statistical difference or permeability to gases was similar. Fruits stored in PE bags without sawdust recorded significantly shorter pre-climacteric period and high build up of condensed moisture compared to those impregnated with dry or moist sawdust. The use of moist sawdust significantly reduced weight loss, but this did not translate into consistent increase in green life period. The reduced weight loss is likely to be due to increased humidity within the storage atmosphere. However, holding fruits in watersaturated atmosphere equally provides favourable conditions for growth of spoilage pathogens [19] and [22]. This study therefore lends support to the use of dry sawdust, which equally achieves same results.

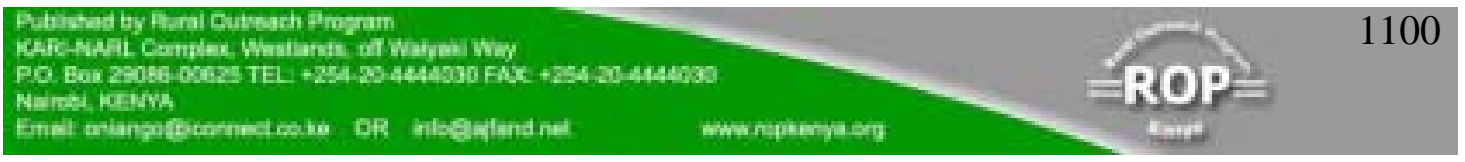


The principal component analysis (PCA) shows that texture alone accounted for greater proportion $(21.8 \%)$ in data variation as by sensory panellists' evaluation. According to [8], once PCA has established patterns and relations in data, the results can be compressed without loss of valuable information. In a similar study, [23] found texture to be the most objective index for identifying effectiveness of storage systems for prolonging plantain green life. Thus, when storing plantain in polymeric to prolong the pre-climacteric period, adequate measures should be taken to keep the $\mathrm{CO}_{2}$ and $\mathrm{O}_{2}$ levels within the optimum levels.

\section{CONCLUSION}

This study has established it is possible to extend the shelf-life of the matured green plantain during the pre-climacteric stage using storage methods based on either passive evaporative cooling or modified atmosphere. In particular, the use of PEC has advantages of prolonging the storage life with minimal effect on sensory and overall consumer acceptability. Households who for lack of appropriate storage methods normally buy only few fingers of plantain for daily sustenance, can purchase few hands to bunches and store for up to two weeks using either of two methods described without incurring losses. 


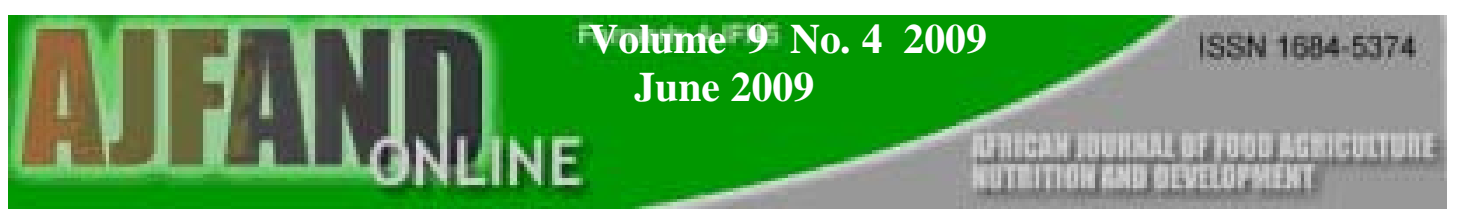

\section{Table 1: Description of treatments for the PEC experiment}

\begin{tabular}{|l|l|}
\hline \multicolumn{1}{|c|}{ Treatments } & Qualitative description \\
\hline Control & Fruits stored at room temperatures \\
\hline Hydro-cooling & Fruits fully immersed in water \\
\hline $25 \% \mathrm{mhc}+\mathrm{SD}$ & Fruits stored in jute sacs moistened such that sacs were moist but not wet \\
\hline $50 \% \mathrm{mhc}+\mathrm{SD}$ & Fruits stored in jute sacs moistened such that sacs were wet, but not water-soaked \\
\hline $75 \% \mathrm{mhc}+\mathrm{SD}$ & Fruits stored in jute sacs moistened such that sacs were water-soaked \\
\hline
\end{tabular}

mhc $=$ moisture holding capacity $\quad \mathrm{SD}=$ sawdust

Table 2: Treatments for Modified Atmosphere Storage Experiments

\begin{tabular}{|c|l|}
\hline Treatment No & Description \\
\hline 1 & Fruits stored in $0.02 \mathrm{~mm}$ LDPE bags only \\
\hline 2 & Fruits stored in $0.02 \mathrm{~mm}$ LDPE bags + dry sawdust \\
\hline 3 & Fruits stored in $0.02 \mathrm{~mm}$ LDPE bags + wet sawdust \\
\hline 4 & Fruits stored in $0.02 \mathrm{~mm}$ LDPE bags + dry sawdust $+\mathrm{KMnO}_{4}$ \\
\hline 5 & Fruits stored in $0.02 \mathrm{~mm}$ LDPE bags + wet sawdust $+\mathrm{KMnO}_{4}$ \\
\hline 6 & Fruits stored in $0.03 \mathrm{~mm}$ LDPE bags only \\
\hline 7 & Fruits stored in $0.03 \mathrm{~mm}$ LDPE bags + dry sawdust \\
\hline 8 & Fruits stored in $0.03 \mathrm{~mm}$ LDPE bags + wet sawdust \\
\hline 9 & Fruits stored in $0.03 \mathrm{~mm}$ LDPE bags + dry sawdust $+\mathrm{KMnO}_{4}$ \\
\hline 10 & Fruits stored in $0.03 \mathrm{~mm}$ LDPE bags + wet sawdust $+\mathrm{KMnO}_{4}$ \\
\hline
\end{tabular}

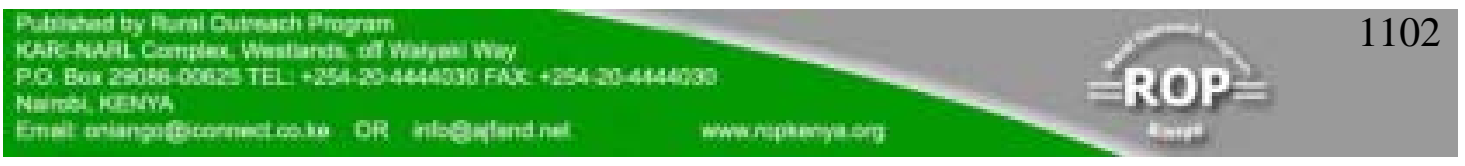




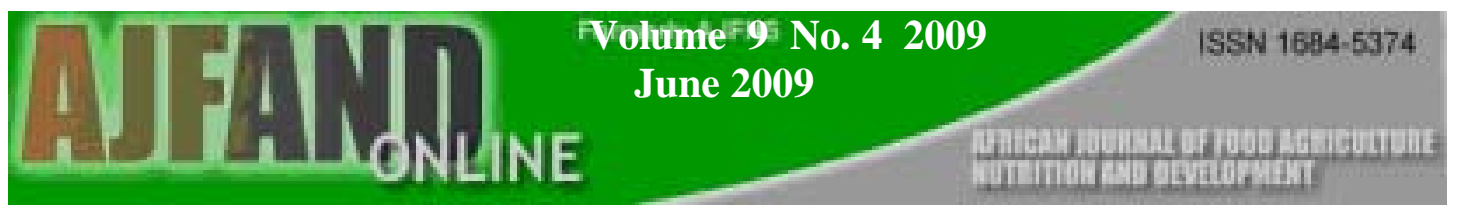

Table 3: Description of quality attributes for sensory evaluation

\begin{tabular}{|c|c|c|c|c|c|c|}
\hline $\begin{array}{c}\text { Hedonic } \\
\text { Scale }\end{array}$ & $\begin{array}{c}\text { Taste } \\
\text { (sweetness) }\end{array}$ & $\begin{array}{c}\text { Flavour } \\
\text { (characteristic } \\
\text { smell \&aroma) }\end{array}$ & Mouth feel & Colour & $\begin{array}{c}\text { Texture } \\
\text { (hardness } \\
\text { or softness) }\end{array}$ & $\begin{array}{c}\text { Overall } \\
\text { acceptability }\end{array}$ \\
\hline 5 & $\begin{array}{c}\text { Extremely } \\
\text { sweet }\end{array}$ & Extremely strong & Excellent & $\begin{array}{c}\text { Very } \\
\text { yellow }\end{array}$ & Very hard & Excellent \\
\hline 4 & Very Sweet & Very strong & Very good & Yellow & Hard & Very good \\
\hline 3 & Sweet & Strong & Good & $\begin{array}{c}\text { Pale } \\
\text { yellow }\end{array}$ & Slightly hard & Good \\
\hline 2 & Slightly sweet & Slightly strong & Fair & $\begin{array}{l}\text { Slightly } \\
\text { yellow }\end{array}$ & Soft & Fair \\
\hline 1 & No sweetness & Off-flavours & Dislike & $\begin{array}{l}\text { Almost } \\
\text { white }\end{array}$ & Very soft & Dislike \\
\hline
\end{tabular}




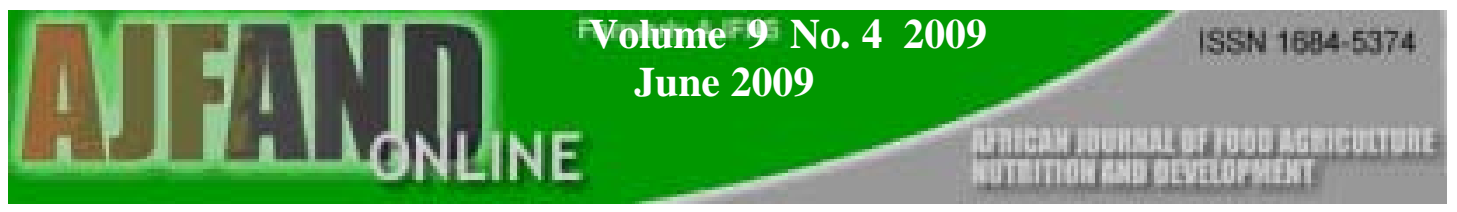

Table 4: Effect of modified atmosphere on number of days at pre-climacteric stage

\begin{tabular}{|c|c|c|c|c|c|c|c|c|c|c|}
\hline \multirow{3}{*}{ Treatments } & \multicolumn{5}{|c|}{$0.02 \mathrm{~mm}$ Thick LDPE } & \multicolumn{5}{|c|}{$0.03 \mathrm{~mm}$ Thick LDPE } \\
\hline & \multicolumn{4}{|c|}{ Varieties } & \multirow{2}{*}{$\begin{array}{l}\text { PET * } \\
\text { TRT }\end{array}$} & \multicolumn{4}{|c|}{ Varieties } & \multirow{2}{*}{$\begin{array}{l}\text { PET * } \\
\text { TRT }\end{array}$} \\
\hline & Apem & Apentu & Asamienu & Oniaba & & Apem & Apentu & Asamienu & Oniaba & \\
\hline PE only & 10.8 & 10.0 & 8.83 & 12.3 & 10.5 & 11.8 & 11.7 & 10.7 & 12.0 & 11.5 \\
\hline Dry sawdust & 16.8 & 14.7 & 11.2 & 14.3 & 14.3 & 14.7 & 14.5 & 13.7 & 13.5 & 14.1 \\
\hline Moist sawdust & 15.7 & 11.7 & 10.8 & 15.5 & 13.7 & 15.7 & 14.0 & 12.8 & 17.0 & 14.2 \\
\hline $\begin{array}{l}\text { Dry Sawdust } \\
+\mathrm{KMnO} 4\end{array}$ & 17.8 & 15.3 & 11.8 & 18.0 & 15.8 & 21.3 & 16.5 & 17.8 & 14.2 & 18.2 \\
\hline $\begin{array}{l}\text { Moist sawdust } \\
+\mathrm{KMnO} 4\end{array}$ & 19.2 & 16.7 & 12.2 & 18.8 & 16.7 & 19.2 & 17.8 & 15.8 & 17.3 & 17.5 \\
\hline Variety & 16.4 & 14.3 & 12.6 & 15.3 & 14.4 & 16.4 & 14.3 & 12.6 & 15.3 & 15.1 \\
\hline $\mathrm{PET} * \mathrm{VAR}$ & 16.3 & 13.7 & 10.9 & 15.8 & & 16.5 & 14.9 & 14.2 & 14.8 & \\
\hline
\end{tabular}




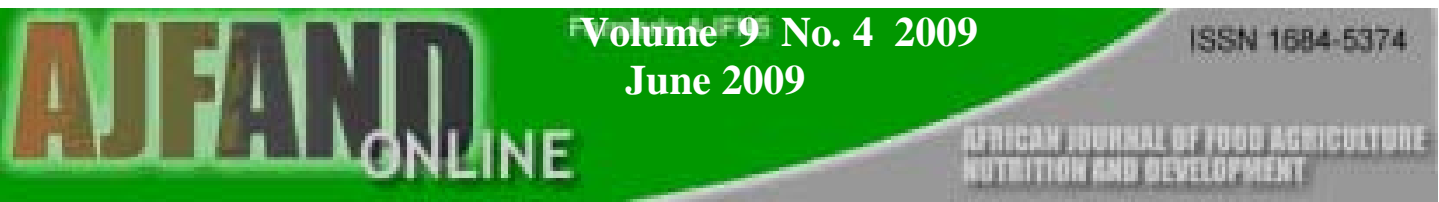

Table 5: Effect of moisture holding capacity on number of days at senescence of four plantain varieties

\begin{tabular}{|c|c|c|c|c|c|}
\hline \multirow[t]{2}{*}{ Treatment } & \multicolumn{4}{|c|}{ Variety } & \multirow[t]{2}{*}{ Treatment } \\
\hline & Apem & Apentu & Asamienu & Oniaba & \\
\hline Control & 3.7 & 3.9 & 3.4 & 3.7 & $3.7^{b}$ \\
\hline $25 \% \mathrm{mhc}$ & 5.0 & 4.1 & 4.3 & 4.3 & $4.4^{\mathrm{a}}$ \\
\hline $50 \% \mathrm{mhc}$ & 4.9 & 4.4 & 4.0 & 4.0 & $4.3^{\mathrm{a}}$ \\
\hline $75 \% \mathrm{mhc}$ & 4.9 & 4.9 & 4.0 & 4.3 & $4.5^{\mathrm{a}}$ \\
\hline $100 \% \mathrm{mhc}$ & 2.1 & 2.1 & 2.1 & 2.1 & $2.1^{\mathrm{c}}$ \\
\hline Variety & $4.1^{\mathrm{a}}$ & $3.9^{\mathrm{ab}}$ & $3.6^{6}$ & $3.7^{\mathrm{b}}$ & 3.8 \\
\hline $\operatorname{LSD}_{(0.05)}$ & \multicolumn{5}{|c|}{ Treatment $=0.382$, Variety $=0.343$, Interaction $=\mathrm{NS}, \mathrm{CV}=3.8 \%$} \\
\hline
\end{tabular}

Treatment and variety means in columns and rows with same letters do not significantly vary 


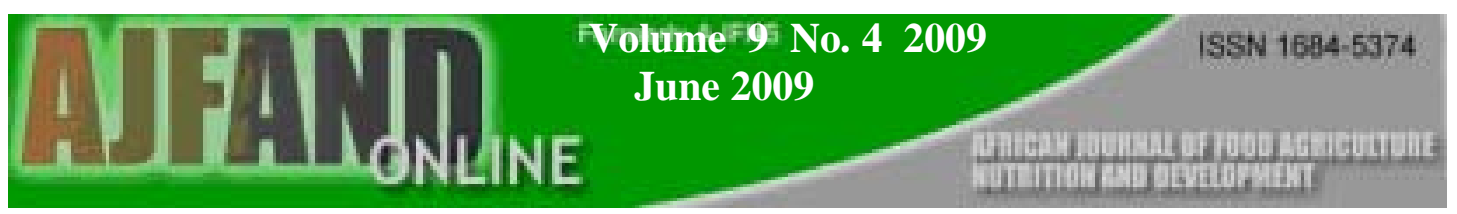

Table 6: Effect of modified atmosphere on number of days of pre- and postclimacteric stages of four varieties of plantain

\begin{tabular}{|c|c|c|c|c|c|c|c|c|c|c|}
\hline \multirow{3}{*}{ Treatments } & \multicolumn{5}{|c|}{ 0.02mm Thick LDPE } & \multicolumn{5}{|c|}{$0.03 \mathrm{~mm}$ Thick LDPE } \\
\hline & \multicolumn{4}{|c|}{ Varieties } & \multirow{2}{*}{$\begin{array}{l}\text { PET * } \\
\text { TRT }\end{array}$} & \multicolumn{4}{|c|}{ Varieties } & \multirow{2}{*}{$\begin{array}{l}\text { PET * } \\
\text { TRT }\end{array}$} \\
\hline & Apem & Apentu & Asamienu & Oniaba & & Apem & Apentu & Аsатіепи & Oniaba & \\
\hline PE only & 16.2 & 15.7 & 14.5 & 17.8 & 16.4 & 17.5 & 17.0 & 16.7 & 17.2 & 17.1 \\
\hline Dry sawdust & 22.2 & 20.5 & 14.5 & 19.7 & 19.7 & 20.2 & 19.8 & 18.8 & 19.3 & 19.5 \\
\hline Moist sawdust & 22.0 & 17.3 & 15.8 & 19.0 & 19.0 & 21.8 & 19.5 & 18.5 & 19.0 & 19.7 \\
\hline $\begin{array}{l}\text { Dry Sawdust } \\
+\mathrm{KMnO} 4\end{array}$ & 22.8 & 20.7 & 17.7 & 22.0 & 21.4 & 27.8 & 24.0 & 22.8 & 22.0 & 24.0 \\
\hline $\begin{array}{l}\text { Moist sawdust } \\
+\mathrm{KMnO} 4\end{array}$ & 24.8 & 22.0 & 15.5 & 23.2 & 25.2 & 25.2 & 23.7 & 20.8 & 23.2 & 23.2 \\
\hline Variety & 22.0 & 20.0 & 17.7 & 20.6 & 19.4 & 22.0 & 20.0 & 17.7 & 20.6 & 20.7 \\
\hline PET * VAR & 21.6 & 19.2 & 15.9 & 21.0 & & 22.3 & 20.8 & 19.5 & 20.1 & \\
\hline
\end{tabular}




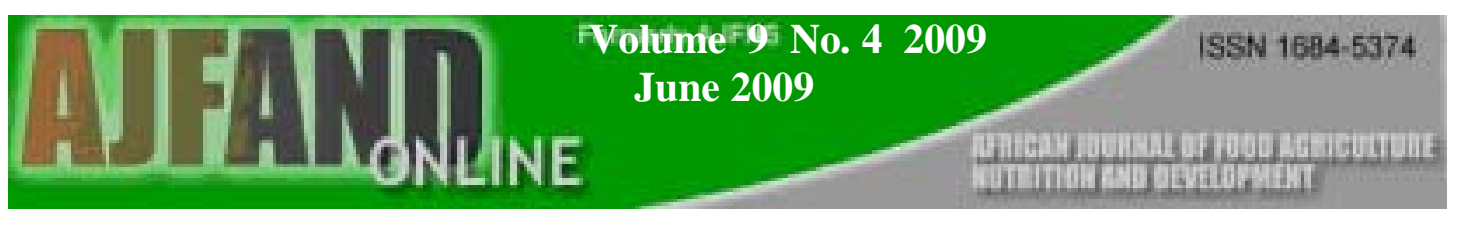

Table 7: Effect of modified atmosphere on physiological weight loss (\%)

\begin{tabular}{|c|c|c|c|c|c|c|c|c|c|c|}
\hline \multirow[b]{3}{*}{ Treatments } & \multicolumn{5}{|c|}{ 0.02mm Thick LDPE } & \multicolumn{5}{|c|}{ 0.03mm Thick LDPE } \\
\hline & \multicolumn{4}{|c|}{ Varieties } & \multirow{2}{*}{$\begin{array}{c}\text { PET } \\
* \\
\text { TRT }\end{array}$} & \multicolumn{4}{|c|}{ Varieties } & \multirow{2}{*}{$\begin{array}{l}\text { PET * } \\
\text { TRT }\end{array}$} \\
\hline & Apem & Apentu & Asamienu & Oniaba & & Apem & Apentu & Asamienu & Oniaba & \\
\hline PE only & 3.79 & 4.46 & 5.25 & 5.09 & 4.65 & 4.52 & 3.35 & 4.41 & 5.09 & 4.17 \\
\hline Dry sawdust & 5.35 & 6.33 & 3.78 & 4.86 & 5.08 & 5.56 & 4.84 & 5.02 & 4.86 & 5.12 \\
\hline & 3.63 & 4.53 & 3.17 & 3.87 & 3.80 & 3.33 & 4.95 & 2.44 & 3.87 & 3.51 \\
\hline $\begin{array}{l}\text { Dry Sawdust } \\
+\mathrm{KMnO} 4\end{array}$ & 6.21 & 6.07 & 4.81 & 5.40 & 5.62 & 5.55 & 4.52 & 5.05 & 5.40 & 5.65 \\
\hline $\begin{array}{l}\text { Moist sawdust } \\
+\mathrm{KMnO} 4\end{array}$ & 54.98 & 4.18 & 4.43 & 4.89 & 4.62 & 5.07 & 5.42 & 3.60 & 3.74 & 4.46 \\
\hline $\begin{array}{l}\text { Variety means } \\
\text { PET *VAR }\end{array}$ & 4.80 & $\begin{array}{l}4.87 \\
5.11\end{array}$ & $\begin{array}{l}4.34 \\
4.29\end{array}$ & $\begin{array}{l}4.67 \\
4.82\end{array}$ & 4.76 & $\begin{array}{l}4.80 \\
4.81\end{array}$ & 4.87 & $\begin{array}{l}4.34 \\
4.38\end{array}$ & $\begin{array}{l}4.67 \\
4.52\end{array}$ & 4.58 \\
\hline
\end{tabular}




\section{REFERENCES}

1. Marriott J and PA Lancaster Bananas and Plantains. In: TC Harvey (Ed Handbook of Tropical Foods. Marcel Dekker, Inc. 1983: 85-142.

2. Treche $\mathbf{S}$ Importance de l'utilisation des racines, tubercules et bananes à cuire en alimentation humaine dans le monde. Les Cahiers de la Recherche Développement, 1997;43: 95-109.

3. Lescot T Banana: production, trade and varieties. Tropical Fruits 2000; (63):13-61.

4. FAO. Food and Agriculture Organization Statistics Division Rome, Italy. 2006.

5. Baiyeri KP, Tenkouano A, Mbah BN and JSC Mbagwu Genetic and cropping system effects on yield and postharvest characteristics of Musa species. Southeastern Nigeria African Crop Science Journal 1999; 7( 1):1-7.

6. Kader AA Modified storage of tropical fruits. In: Postharvest handling of tropical fruits. Proc. Intl. Conf., Chiang Mai, Thailand. 1993: 239-249.

7. Ahmed S, Thompson AK, Perviez MA, Ullah H and ZA Chatha Effect of polyethylene film thickness and exposure time of ethylene on ripening behaviour and quality of banana. International Journal of Agriculture and Biology 2006; 8 (3): 381 -386.

8 Smith LI A tutorial on principal component analysis. pp 1-27. Retrieved at http://www.csnet.otaga.ac.nz 2002.

9. John $\mathbf{P}$ and $\mathbf{J}$ Marchal Ripening and biochemistry of the fruit. In: S Gowen (Ed) Banana and plantain. Champman and Hall, London, 1995;434-467.

10. Robinson JC Banana and plantains. Crop Production Science in Horticulture. (5).CAB International, Wallingford, UK, 1996.

11. Ferris RSB Post-harvest physiology of plantain and plantain. IITA Research Guide (62). Ibadan. at http://www.iita.org/inf.trn_mat/irg62.html, 1997.

12. Thompson AK and OJ Burdon. Harvesting and fruit care. In: S Gowen (Ed). Bananas and Plantains. Chapman and Hall. London, UK, 1995: 403-433.

13 Wills RHH, McGlasson WB, Graham D, Lee TH and EG Hall Postharvest An introduction to the physiology and handling of fruit and vegetables. $3^{\text {rd }} \mathrm{Ed}$. Blackwell Science Publication, Oxford, UK.1998; 176.

14. Johnson PNT and M Hodari-Okae Influence of wood species on moist sawdust storage of tomatoes. Tropical Science 1999; 39: 214-219.

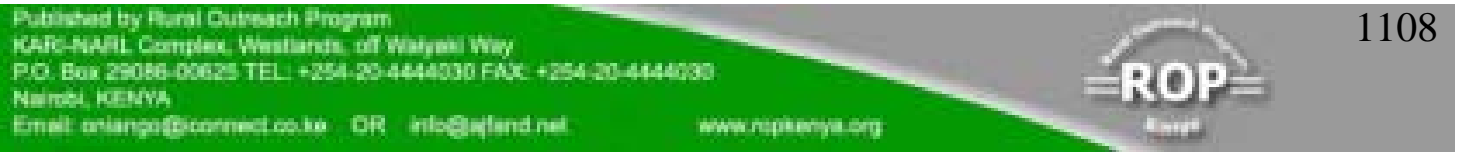


15. Opera LU, Studman DJ and HN Banks Fruit peel splitting and cracking. HortReview 1997; 19: 217-262.

16. Wo SM, Osman A, Ahmad SH and N Saari Peel and pulp splitting disorder in Mas banana (Musa Cv Mas (AA). Journal of Agric. and Environment 2005; 3 (2):213-217.

17 Kubo Y, Inaba A and $R$ Nakamura Respiration and $\mathrm{C}_{2} \mathrm{H}_{4}$ production in various harvested crops held in $\mathrm{CO}_{2}$-enriched atmospheres. Journal of the American Society for Horticultural Science 1990; 115: 975-978.

18 Yahia EM Modified and control atmosphere storage of tropical fruits. Horticultural Reviews 1998; 22:123-183.

19. Bishop D Controlled atmosphere storage In: C.J.V. Dellino (Ed). Cold and Chilled Storage Technology. Blackie, London.1990: 66-98.

20. de Wild HP, Otma EC and HW Peppelenbos Carbon dioxide action on ethylene biosynthesis of pre-climacteric and climacteric pear fruit. Journal of Experimental Botany 2003; 54: 387, 1537-1544.

21. Kende H Ethylene biosynthesis. Annual Review of Plant Physiology and Plant Molecular Biology, 1993; 44: 283-307.

22. Hernandez I Storage of green plantains. Journal of Agriculture of the University of Puerto Rico 1973; 57(2): 100-106.

23. Baiyeri KP Effect of rice husk, sawdust and their admixtures as storage media and polyethylene on the green life span and culinary qualities of mature plantain (Musa sp. AAB) fruits. Agro-Science 2001; 2(2): 19-25. 